\title{
Financial Stability of Islamic Versus Conventional Banks in Pakistan
}

\author{
Tanveer Abrar ${ }^{1}$, Farhan Ahmed ${ }^{2}$, Muhammad Kashif ${ }^{3}$
}

\begin{abstract}
This study aims to analyze and compare the financial stability of Pakistani banks covering a timeframe of 5 years from 2012 to 2016. This study employs the financial soundness indicators of the International Monetary Funds and State Bank of Pakistan and the z-score index. The comparative analysis through average scores is performed using 3 indicators of financial stability namely Z-Score, Capital Adequacy Ratio (CAR) and Equity to Total Assets Ratio. The findings of the research reveal that (i) conventional banks are more financially stable than Islamic banks; (ii) large conventional banks are more financially stable than large Islamic banks; (iii) small Islamic banks are less stable than small conventional bank. The implication of this paper is that conventional banks have the potential of absorbing financial stability shock as compare to Islamic banks on the basis of stated financial soundness indicators and Z-Score specifically.
\end{abstract}

Keywords: Islamic banks, conventional banks, financial stability.

\begin{abstract}
Abstrak. Penelitian ini bertujuan untuk menganalisis dan membandingkan stabilitas keuangan bank Pakistan yang mencakup jangka waktu 5 tahun dari 2012 hingga 2016. Studi ini menggunakan indikator kesehatan keuangan dari Dana Moneter Internasional dan Bank Negara Pakistan dan indeks z-score. Analisis komparatif melalui skor rata-rata dilakukan menggunakan 3 indikator stabilitas keuangan yaitu Z-Score, rasio kecukupan modal (CAR) dan rasio ekuitas terhadap total aset.. Temuan penelitian mengungkapkan bahwa (i) bank konvensional lebih stabil secara finansial daripada bank syariah; (ii) bank-bank konvensional besar lebih stabil secara finansial daripada bank-bank Islam besar; (iii) bank-bank Islam kecil kurang stabil daripada bank konvensional kecil. Implikasi dari makalah ini adalah bahwa bank-bank konvensional memiliki potensi menyerap guncangan stabilitas keuangan dibandingkan dengan bankbank Islam atas dasar indikator kesehatan keuangan dan Z-Score khusus.
\end{abstract}

Kata Kunci: bank syariah, bank konvensional, stabilitas keuangan.

\section{How to Cite:}

Abrar, T., Ahmed, F., \& Kashif, M. (2018). Financial Stability of Islamic Versus Conventional Banks in Pakistan. Al-Iqtishad: Jurnal Ilmu Ekonomi Syariah (Journal of Islamic Economics). Vol. 10 (2): 341 - 366. doi: http://dx.doi.org/10.15408/aiq.v10i2.6500. 


\section{Introduction}

Globally Islamic banking finance (IBF) growth is increasing with fastpace, and remarkable growth has been observed. As per the joint study of Edbiz Consulting and Cambridge IF Analytica, Islamic banking and finance projected size as a globally at the end of December 2016, is around USD 2.293 trillion (Thomson Reuters ZAWYA [TRZ], 2017). According to Derbel, Bouuraoui and Dammak (as cited in Odeduntan, Adewale \& Hamisu, 2016), multiple factors are contributing to Islamic banking rapid growth. First, Muslim populations are increasing in the world and who are willing and craving to use Shariah-compliant product in their business need. Second, the effectiveness and remarkable growth and performance of Islamic banks are up till now additional motivation to the frequent progress of the Islamic industry. Finally, the statistic that system of Islamic banking depends on high values of ethical which are not allowed to invest in that portfolio which forbidden in Islam such as alcohol, speculation, interest, illegal investment activities, pork, prostitution, gambling, pornography, etc. It motivated and allowed capitalizing on real assets.

It has noted that in the conventional banking system are working in the way where conversion of wealth from poor society to wealthy society and from developing countries to developed countries; therefore, grudging the poor community is poorer. The more and extreme usages of Interest, structured debt and securitization are the symbol of this situation (Odeduntan, Adewale \& Hamisu, 2016). Islamic product financing is operating by justice and fairness in financial and equity in society. These are the basic requirement and foundation. In conventional banking, repayment of financing to the investor gives in term of interest, and the rate of interest is fixed and the beneficiary accountable for any risk associated with financing activities. Opposing to this, In Islamic banking, repayment of financing to the investor gives in term of profit and loss and risk associated with financing activities are shared with beneficiary and bank. Therefore, if investor and financer invest in Islamic banking than they are not only received profit merely and they are also expecting potential risk that is shared between financer and bank. This is the fact that Islamic banking has beefed up to replace and exchange the banking sector of the conventional bank and its growth as a steady and equitable. In Asia, Middle East, and Africa, its development and growth are mentioning in this region. In Western economies, Islamic system is evolving and also developing which was not observed in the past, and their need and requirement have been noted therefore central bank of the countries are working and strangling in creating of Islamic banking window for coping of Shariah-compliant product need.

In the system of economic, financial stability topic is crucial and essential 
because financial system delivers a springboard for furthermost of activities and operational transaction that are operating in the real economy. Stability of banking sector is playing a critical role in economic growth and development, and economic stability depends on large banking sector financial stability. We cannot deny the role and participation of banking sector for the growth of the economy and its development. Financial stability is continually drawing attention in professional and academic research since we have learned a lesson in global financial meltdown and it is necessary to know that mechanisms of keeping and maintain financial stability.

Pakistan economic condition is uncertain due to internal factors such as political uncertainty, unrest law, and order situation, conditional government policy. The internal factors, as well as an external factor such as IMF unfavorable condition, international oil pricing fluctuation, international trade strike, exchange rate, etc. therefore financial risk, operational and credit risk, is prevailing in Pakistan. Due to this reason bank are facing financial stability issues in Pakistan.

Financial stability of banking sector is very essential for growth of the economy. Role of banking sector cannot be denied in overall economic development because the stability of any economy is dependent on the stability of its banking sector. To reduce anomalies in Pakistan economic sector, it is necessary to develop new banking structure in Pakistan economy. Maintaining financial stability in the banking sector is a big challenge now a day in Pakistan. To cope this dilemma, the banking sector is adopting strict compliance with risk management.

The financial institution is a backbone of the economy. The financial institution is playing a vital role in economic growth of Pakistan. During economic expansion, the financial institution provides financing that pushes economic growth; therefore, financial stability is an important factor in the overall banking sector. Due to this reason, I want to examine and compare the financial stability of selected Pakistani banks from both Islamic banking industry and conventional banking industry.

Due to financial stability crises bank are merging. Recently HSBC bank has closed their Pakistan operation and merged with Meezan Bank Ltd. NIB Bank merged with MCB Bank \& Burj Bank merged with Bank Al Baraka due to financial stability crises. According to Keynes income of individual and institution is dependent on investment. Increase in investment that increases in total income, but the impact on income is greater than the initial investment. For example, if we invest one lack rupee in the economy than total income will be increased by three lack. Its means multiplier is equal to three provided that financial institution and the individual will take percussion such as risk assessment, business risk review and financial stability assessment before investment in any portfolio, therefore, it is 
necessary for all Pakistani banks to develop effective and efficient internal control system and risk assessment department for maintaining its financial stability.

In 1971, Nasser Social Bank was established as first Islamic banks mean Interest-free banks in Egypt. The Muslim government first time had presented and shown willingness and interest for development and incorporating Islamic banking institution. The purposes of Nasser Social Bank in Egypt is social welfare to the country such as help of needy and poor person in term of providing easy and without interest charge loan, assist in students for completing of study in term of grant scholar, provided microloan to the small businessman for its project on the basis of sharing profit as well as loss. On private initiative, the first Islamic bank in the United Arab Emirates (UAE) 1975 was Dubai Islamic Bank in the world.

In Pakistan, Meezan Bank the first Islamic banks established in 2002 and Justice (Retd) Muhammad Taqi Usmani is chairman of shariah supervisory board. State Bank of Pakistan was established Islamic banking department in 2003 in Pakistan. Guideline and instruction for shariah product compliance and monitoring for Islamic were issued in 2008. In Islam, allowed trading base activity and prohibited interest. In Europe, Muslim introduced trade. Musharaka and Mudaraba is the main financing mode in Islamic banking through which trading activities and financing activities are conducting in Islamic Banks. Profit and income generated by Islamic banks form an investment in the different portfolio are distributed and share according to profit and loss sharing ratio. There is no fixed rate of return on investment in Islamic banking sector whereas in conventional banking sector fixed profit is being distributed to the investor, depositor, and customer. Al-Hadith and al-Quran are basis sourced from the industry of Islamic banking, and it provides clear guideline and rules for execution of a transaction in Islamic banking. There is some limitation in Islamic banking for accepting deposit and investment point of view because of Islam verboten that investment which is not in line with shariah sources. In Islamic banking, activities that base on interest with the effect of multiplier and speculation are not allowed. (Iqbal and Mirakhor 2011; Iqbal et al., 2011).

Bank financial stability is very essential in the economic system. The financial institution is a bridge for economic growth and development. Bank financial stability is a big challenge in Pakistan due to this dilemma banks are merging in Pakistan and facing financial crises. The objectives of the study are: first, to determine whether conventional banking system is more financially stable than Islamic banking system. Second, to find out that large conventional banks are more financially stable than small Islamic banks. Third, to find out that small conventional banks are more 
financially stable than small Islamic banks. Fourth, to determine which Islamic bank in more financially stable in all Islamic Banks. Fifth, to determine which conventional bank is more financially stable in all conventional banks.

\section{Literature Review}

Conventional and Islamic banking, Shariah compliance is a key differentiating factor. We have been noted that there is the rapid growth of global Islamic banks over the year due to Shariah compliance mechanisms. Since Islamic banking is nascent industry, in comparison to conventional banks. Specifically, It has been founded that there are little work and paucity in the literature on the financial stability of Conventional \& Islamic Bank. Empirical studies on financial stability between conventional and Islamic banking was still rare (Wahid and Dar 2016) and Odeduntan et al. (2016). In conventional banking fixed rate of return on investment is paid/ received whereas, in Islamic banking, there is profit and loss sharing ratio between investor and depositor (Hasan and Dridi, 2010).

Islamic banking has been established on the basis of sources of Islam i.e. the al-Quran and al-Hadith. These sources provide guidelines and basic principles to Islamic banking industry for its operations activities and decision making for investment purpose. There is some limitation in Islamic banking because it is prohibited that investment which is not underlined and accordance with sources of Islam. Interest base activities with multiplier effect and speculation are prohibited in Islamic banking industry (Iqbal and Mirakhor 2011; Iqbal, et al, 2011).

Practical situation most financing transaction in Islamic banking is not based on profit and loss sharing principle (Chong and Liu, 2009) but we do not agree with this statement because, in Pakistan, State Bank of Pakistan has separate shariah compliance department. It consists of highly qualified shariah scholar and they are strictly monitoring of Islamic banking in Pakistan and its operation. Financial institution and Banks are working as intermediaries and play an important role economic development that collected fund from the depositor and investing in the different product portfolio through different channels and distributes profit and loss according to agreed sharing ration and predetermined profit and loss sharing ratio. Banks have the ability, expertise and knowledge full information and placed surplus money in a productive investment in order to achieve maximization of profit. In order to minimized risk such as credit risk, market risk, liquidity risk, operational risk and reputational risk, it is necessary for all banking sector industry in worldwide to must have assessment professional and conduct a risk assessment before investing in the different portfolio (Bessis 2010). 
Youssef (2017) investigated the subject topic. He selected gulf region in which he selected 12 banks in 4 countries. There were 5 Islamic and 7 conventional banks for analyzing and determining the financial stability of the conventional and Islamic bank. In his study, he used 10 year sample period from 2006 to 2015. He collected data from a different website such Federal Reserve and World Bank. In this research they used Z-Score for measurement of the financial stability of bank and Z-Score is calculated by leverage and return of the asset. The object of this study was to analyze which banking sector is more financially stable in the banking sector during the specified sample period. This study covered during and after financial crises period. He determined that Islamic bank was less stable as compared with conventional banks. As per researcher, this was occurred due to governing and management challenges faced by Islamic banks in Islamic banking industry. Remarkably, it had been observed that Islamic banks were performing well as compared with the conventional bank in the duration of financial crises. Although, Islamic banks was suffered after crises period, because of a solid relationship between real economy and Islamic banking industry. Islamic banks more invested in a real asset, therefore, these banks suffered in global financial crises.

Research conducted by Karim et al. (2016) in which they analyzed financial stability between Islamic and conventional bank. They selected 131 banks for analyzing purpose in which there were 77 commercial and 54 Islamic banks in MENA countries MENA countries means the Middle East and North Africa. Sample period was from 1999 to 2015. They collected data from Bureau Van Dijk for analyzing the purpose of bank financial stability. In this research they used Z-Score for measurement of the financial stability of bank and Z-Score is calculated by the return of asset and earning to the total asset. The object of this study was to analyze which banking sector is more financially stable in the banking sector during the specified sample period. Global financial crises also observed by a researcher in this study during analysis of financial data. After analysis of data, they conclude that Islamic banking industry was more financially sound as compared with the Conventional Banking industry in specified selected countries. In addition, they also analyzed that during financial global crises 2007-2009 only conventional banking industries were suffered and affected by financial crises and Islamic banks was not affected and they were not in troubled condition from financial crises in MENA countries. As per my opinion, Islamic Bank was investing into secure financing capital asset; therefore, Islamic Banks were secure in MENA countries during financial crises period.

Equally, Odeduntan et al. (2016) analyzed and determined financial stability 
between the conventional and Islamic bank of Malaysia country. They analyze 16 Islamic banks in Malaysia and time frame for this study was from 2008 to 2012. Data were collected and extracted form relent bank website for analyzing purpose. The researchers used Z-score for measurement of the financial stability of bank and Z-Score is calculated by Loan to deposit ratio, liquidity ratio and Non-performing loan (NPL). After compared and assessed by the Islamic and conventional bank, the concluded that in Malaysia Islamic bank is more stable as compared with a conventional bank. Z-Score was high of an Islamic bank; therefore, it proved that Islamic bank more stable in Malaysia. Its means total equity was high on total asset and return on asset was also high in a selected Islamic bank.

Similarly, Cihak and Hesse (2010) analyzed and compared Islamic and conventional bank. They analyze 474 banks in which included 77 Islamic banks and 397 commercial banks. Sample period was from 1993 to 2004. They analyzed and compared small Islamic banks with small conventional banks and large Islamic banks with large conventional banks and they divided banks into the small and large scale on the basis of deposit size. The researcher used $\mathrm{Z}$ score, loan to total asset and cost income ratio for measurement of bank financial stability. They concluded that small Islamic banks are more stable as compared with the small conventional bank and simultaneously large conventional bank more stable as compared with a large Islamic bank. Large Islamic banks are less stable because of irregularities in the monitoring of credit risk and small Islamic bank more stable because they were more concerned with risk assessment and risk management in investment. Small Islamic banks were more stable with a large Islamic bank.

In addition, Wahid and Dar (2016) analyzed the financial stability between a conventional and Islamic bank in Malaysian framework. They analyzed 17 Islamic and 21 conventional banks and time frame for this study was from 2004 to 2013. The researcher used such as $\mathrm{Z}$ score, equity to total asset, non-performing loan (NPL), the cost to income ratio (CIR), Return on equity, net loan to a total asset for measuring of financial stability. They determined that Islamic banks in term of large were less stable as compared with conventional banks in term of large in Malaysian and an Islamic bank in term of small was more stable as compared with the conventional bank in term of small. The researcher used financial soundness indicators (FSIs) of the IMF and the Z-score. Secondly, the researcher examined that size of the bank; capitalization level and diversification of income were key determinants for the stability of Malaysian Islamic industry banks and conventional industry banks.

Similarly, Chakroun and Gallali (2015) also investigated on the same topic and their finding matched with Wahid and Dar (2016). They determined that small 
conventional banks are less financially stable as compared with small Islamic banks and large Islamic banks less financially stable as compared with large conventional banks. Their finding and result showed that in financial crises era conventional banking industry was more affected as compare with Islamic banking industry. Cihak and Hesse (2010) reported also their fact and findings to be a match and consonant with Wahid and Dar (2016) and Chakroun and Gallali (2015).

Equally, Ibrahim (2015) compared two Islamic banks in UAE like Dubai Islamic Bank and Abu Dhabi Islamic bank analyzed and measured financial performance between two banks. Researcher used time frame for this study from 2003 to 2007. Data was collected from bank website and Abu Dhabi financial service company. To measurement of financial performance between two banks he used different financial ratio for analyzing of bank liquidity, profitability, management capacity, capital structure and share performance of the bank and used Z score for measurement of financial stability between two Islamic banks. The researcher concluded and found that both Islamic banks were financially sustainable and both banks had the effective financial instrument and rules and regulation for organizing and utilization of resources in order to the achieved maximization of bank profit. The liquidity ratio in Dubai Islamic bank was less as compared with its competitive bank. The researcher found that Dubai Islamic bank had higher profitability and variability as compared with Abu Dhabi Islamic bank. $\mathrm{Z}$ score calculated by return on asset total equity on the total asset. When researcher calculated $\mathrm{Z}$ score for measurement of financial stability, he found that Abu Dhabi Islamic bank had higher financial stability as compared with Dubai Islamic bank in UAE.

Beside, Hasan and Dridi (2010) analyzed that conventional and Islamic bank during global financial crises and they learned that how the Islamic banks were affected by financial crises period different from a conventional bank. They recognized this difference to the dissimilar business models used by the two baking industries. They additional discovered that asset growth in Islamic banks was better as compared with conventional banks and their rating by outside agencies was more satisfactory.

In the similar topic, Shahid and Abbas (2012) also analyzed and compared financial stability between Islamic and conventional bank. They analyzed 16 banks in Pakistan in which there were 6 Islamic banks and 10 top rated conventional. The sample periods were used from 2006 to 2009 for comparing of the Islamic and conventional banking industry in Pakistan. They divided conventional and Islamic bank into the small and large bank on the basis of the average total asset. The researcher used $\mathrm{Z}$ score for comparing and identifies financial stability between both banking sector Islamic and conventional. $Z$ score also used by the different researcher 
for comparing of financial stability. They researcher computed and concluded that small Islamic banks had high Z score as compare with small Islamic bank, therefore, proved that small Islamic banks were more stable than small conventional bank and simultaneously large conventional had high $\mathrm{Z}$ score as compare with large Islamic bank, therefore, proved that large conventional banks were more stable than large Islamic bank in Pakistan in the specific sample period. It is also proved that small Islamic bank had high $\mathrm{Z}$ score as compared with large Islamic bank, therefore, small Islamic more financially stable than large Islamic bank. In overall perspective as the whole regardless size of the bank, Islamic bank had high Z score as compared with conventional bank hence proved that Islamic bank was more financially stable over conventional banks as a whole perspective.

Equally, Rahim and Zakaria (2013) analyzed and compared 17 Islamic and 21 conventional banks of Malaysia and on the basis of financial data extracted from bank official website; they conclude that average Islamic bank was more stable as compared with a conventional bank. They used Z score and NPL (Non-Performing Loan) as proxies for the stability of the bank. The sample periods were from 2005 to 2010 for analyzing of the financial stability of conventional and Islamic bank and simultaneously Verbeet (2014) analyzed and compare Islamic and conventional banks in Malaysia. They selected total 5 banks as a sample size in which there were two Islamic and three conventional banks. They determined that Islamic banks were not stable and conventional banks have well (liquidity, performance and capital adequacy ratio) than Islamic bank. As per my opinion verbeet used small sample size for measurement of financial stability between conventional and Islamic banks. He should have increased sample size for measurement and determination of financial stability.

Similarly, Rajhi and Hassairi (2013) also investigated the subject topic for a sample of 467 conventional banks and 90 Islamic banks selected from 16 countries of Southeast Asian and MENA regions. The time span ranged from 2000 to 2008. To measure the financial stability, Z-score model was employed. They found Z-scores to be higher for Islamic banks (except for small Islamic banks) than those for conventional banks signifying higher stability of Islamic banks.

Furthermore, Bourkhis and Nabi (2013) used Z-score as an indicator of bank stability, compared and contrasted the financial soundness of the Islamic versus conventional banks during the 2007-2008 financial crisis. Their findings showed no significant difference in terms of the impact of the financial crisis on the soundness of both counterpart industries. This means that Islamic banks are diverging from their theoretical business model that would have allowed them to keep the same level of soundness even during the crisis (Bourkhis \& Nabi, 2013). Another similar 
study by Beck, et al (2013) published in the same year found some noteworthy facts about the Islamic banks. The results said that Islamic banks are less cost-effective, but have a higher intermediation ratio, higher asset quality, are better-capitalized and less likely to disintermediation during crises. Beck et al. (2013) further argued that the better stock performance of listed Islamic banks during the recent crisis is also attributable to their higher capitalization and better asset quality. Siraj and Pillai (2012) found a better performance of Islamic banks in GCC region. Their analysis revealed that Islamic banks are more equity financed than conventional banks.

Consistent with the results and finding of the researcher completed by Johnes, Izzeldin, and Pappas (2009), Beck et al. (2013), used ratio financial analysis and concluded that in term of cost-efficient, Islamic Banks are less stable but more profit and revenue efficient as compared with conventional banks. Bitar et al (2015), Johnes et al. (2009) also used a ratio of financial and discovered and conclude that conventional banking industry is more stable as compared the Islamic bank's counterparts. In contrast, Due to the negative liquidity and leverage, conventional banks were suffered (Nafla and Hammas, 2016). Hasan and Dridi (2010) conclude that Islamic banks growth of asset was better than the industry of conventional banks.

In the same manner, Islam and Kozokov (2009) also analyzed and compare financial stability between conventional and Islamic banks. The sample size was 66 banks in which there were 26 Islamic banks and 40 conventional banks. They selected Islamic and conventional bank from different countries like (Bahrain, Kuwait, Qatar, Saudi Arabia, United Arab Emirates, Pakistan, Malaysia, and United Kingdom). The sample period was from 2005 to 2008. They used (Z score, NPL, the cost to income ratio, loan to Asset and income diversity) for measurement of financial stability. They determined that $\mathrm{Z}$ score was quite same for conventional and Islamic banks. They found and conclude that there was no significant risk between conventional and Islamic bank during the year 2005-2008. There was no evidence of stability differences between Islamic and conventional banks in global financial crises era 2008.

In the similar study, Beside, Farook and Hassan (2015) also analyzed financial stability between conventional and Islamic banks. They also used $\mathrm{Z}$ score for measuring financial stability. They selected 50 Islamic banks and 150 sound conventional banks from multiple countries likes (Algeria, Bahrain, Bangladesh, Egypt, Indonesia, Jordan, Kuwait, Malaysia, Pakistan, Qatar, Saudi Arabia, Senegal, Tunisia, Turkey, United Arab Emirates and Yemen. Iran and Sudan). Sample period was from 1991 to 2005. They conclude that Islamic banks were not financially stable as compared with conventional banks. 
In the same manner, Rokhim \& Gamaginta (2009) also analyzed and compared financial stability between Islamic and conventional banks of Indonesia. The purpose of this study to determine which banking sector either Islamic sector or Conventionalbanking sector is most financially stable in Indonesia. The researcher uses select 83 banks as a sample size in which there were 12 Islamic banks and 71 conventional banks of Indonesia. The sample period was from 2004 to 2009. They also used Z score for measuring of financial stability between conventional and Islamic bank. The researchers used bank return on asset and total equity of the bank on total asset of the bank for $\mathrm{Z}$ score calculation. The researcher found that there was higher and substantial volatility in return of asset in Islamic banking industry in 2004 to 2005. It had been noted that return on asset was negative in quarter fourth in 2008 due to multiple reasons one reason was worst situation in the non-performing loan. Simultaneously average return on asset of the conventional banking sector was stable and only minor decreasing rate in average return on the asset in the year ending closing 2008. After analyzed the Indonesia banking sector the researchers determined that conventional banks were more stable in general as compared with Islamic banking sector in Indonesia country. Demirguç-Kunt and Detragiache (2009) also recommended that z score is the best technique for measurement of the financial stability of banks.

Similarly, Uhde and Heimeshoff (2009) analyzed financial stability of banks of European Union countries and found that national banking sector in EU countries does not have a positive impact on financial stability of private banks of European countries. Santoso et al. (2016) used Z score for measurement of financial stability between conventional and Islamic banks Indonesia and found that conventional banks in Indonesia were more stable as compared with Islamic bank sector in Indonesia because conventional banking sector is investing in secure financing, therefore, they are getting high rate of return on asset and they are generating high profit, therefore, equity to an asset of conventional banks is high than Islamic banks in Indonesia. Altaee et al. (2013) analyzed financial stability of Gulf Cooperation Council (GCC) countries and they found that there were no major differences found in financial stability between conventional and Islamic banks in GCC countries in two eras. Despite the important and rapid growth of Islamic industry in worldwide, Chapra (2011) argued that Islamic banks are working in a financial system where conventional banks are dominant in banking sector industry hence Islamic bank is participating in existing financial and market risks, therefore, that impact on Islamic banking financial stability. As per my opinion, In Pakistan and worldwide, there is no separate Islamic inter-branch offer rate for Islamic banking industry. There must be separate Islamic inter-branch offer rate for its investing and financing activities. This argued also supported by (Rokhim \& Gamaginta 2009; Kassim \& Abd. Majid 2010; Belouafi, Bourakba and Saci 2013; Bourkhis \& Nabi 2013). They 
determined that inadequate impact on Islamic banking financial stability where the conventional bank is dominant.

On the basis of a different research paper, it has been identified that Z-Score analysis and technique is best for measurement of the financial stability of banking sector. In order to maintained and higher financial stability in the banking sector, Banks required to mitigate risk, ensure compliance of standard operating procedure and regulatory requirement and make effective and efficient decision making while financing and investing fund into the different portfolio.

\section{Method}

Secondary data has been obtained from Statistics and Data Warehouse Department of State Bank of Pakistan for analyzing the financial stability between an Islamic and Conventional bank in Pakistan which is collected from Bank Balance sheet, Income statement, Bank official Website and annual report, State Bank of Pakistan and Pakistan stock exchange website and we are using panel data for measuring of the financial stability of banks. The data is collected from 8 banks that are operating in Pakistan. However, there are only 4 Islamic banks merely fullfledge working in Pakistan hence I am using 4 Islamic \& 4 conventional banks that are matched with Islamic banks in term of large and small banks and all the conventional and Islamic banks are maintaining capital requirement of State Bank of Pakistan 10 billion therefore we are using these banks for examine, investigate and comparison of financial stability purpose. Islamic Banks include: Meezan Bank Ltd, BankIslami Pakistan Ltd, Al Baraka Bank and Dubai Islamic Bank Limited and conventional banks include: Habib Bank Ltd, Allied Bank Ltd, Faysal Bank Ltd and Askari Bank Ltd on the basis of market capitalization.

Three financial soundness indicators are used to gauge the objectives of the study and these indicators include Z-score (See Youssef, 2017; Karim et al. 2016; Wahid and Dar, 2016; Santoso et al., 2016; Odeduntan et al., 2016; Ibrahim, 2015; Akhtar, et al, 2013; Beck et al., 2013; Rajhi and Hassairi, 2013; Bourkhis and Nabi, 2013; Shahid and Abbas, 2012; Ali and Sadaqat, 2011; Cihak and Hesse, 2010; Johnes et al., 2009) capital adequacy ratio (CAR) and equity to total assets as used by International Monetary Fund's (IMF) and State Bank of Pakistan (SBP).

Z- Score is important statistical tools and techniques which have been used by a various researcher in their study. It is measure bank financial stability; solvency and insolvency of the individual banks banking sector and insolvency means debts of banks will be increased gradually as compared with assets of banks. It determines and compare (Returns and capitalization) and (volatility in return on asset) for measurement of financial stability and solvency. Higher Z- Score means banks 
have higher financial stability and low Z-Score means banks have lower financial stability. Z-score calculates the financial stability of both banking sector Islamic and Conventional banking sector.

\section{Result and Discussion}

This section covers the discussion of observations and finding of 3 different parameters that has been selected for measuring and assessing of soundness and financial stability between conventional and Islamic banking industry of Pakistan.

\section{Z-Score Analysis for Conventional and Islamic Banking: Measuring Stability}

Average Z-Score (2012-2016) pairwise comparison and analysis in Table 1 between conventional and Islamic bank indicate and show that Conventional banks in Pakistan are more financially stable because they have highest average Z-Score is 170 than Islamic Bank. Islamic bank has lowest average Z-Score is 45 may be a reason and caused by lowest value of equity to the asset, return on asset and higher return volatility means a higher standard deviation of return of the asset.

Table 1. Z-Score Analysis for Conventional and Islamic Banking

\begin{tabular}{cccccc}
\hline Islamic & $\mathbf{2 0 1 6}$ & $\mathbf{2 0 1 5}$ & $\mathbf{2 0 1 4}$ & $\mathbf{2 0 1 3}$ & $\mathbf{2 0 1 2}$ \\
Meezan Bank & 78 & 55 & 79 & 60 & 25 \\
BankIslami & 25 & 19 & 97 & 45 & 34 \\
Dubai Islamic Bank & 30 & 23 & 24 & 29 & 87 \\
Al Baraka Bank & 30 & 101 & 43 & 11 & 7 \\
Average & $\mathbf{4 1}$ & $\mathbf{5 0}$ & $\mathbf{6 1}$ & $\mathbf{3 6}$ & $\mathbf{3 8}$ \\
Average (2012-2016) & $\mathbf{4 5}$ & & & & \\
Conventional & $\mathbf{2 0 1 6}$ & $\mathbf{2 0 1 5}$ & $\mathbf{2 0 1 4}$ & $\mathbf{2 0 1 3}$ & $\mathbf{2 0 1 2}$ \\
HBL Bank & 87 & 886 & 165 & 93 & 38 \\
Allied Bank & 61 & 59 & 69 & 136 & 194 \\
Askari Bank & 71 & 118 & 4 & 3 & 53 \\
Faysal Bank & 259 & 31 & 93 & 113 & 876 \\
Average & $\mathbf{1 2 0}$ & $\mathbf{2 7 4}$ & $\mathbf{8 3}$ & $\mathbf{8 6}$ & $\mathbf{2 9 0}$ \\
Average (2012-2016) & $\mathbf{1 7 0}$ & & & & \\
\hline
\end{tabular}

Source: Annual Report, Pakistani Banks 
It has been analyzed and determined that each selected individual conventional and Islamic banks in Pakistan from time frame 2012 to 2016 means 5-year timespan are stable because each bank is maintaining 3 or more than 3 $\mathrm{Z}$-score. According to Robert Altman, if z-score of banks is greater than and equal to 3 it indicates that banks are financially stable.

Table 2. Average Z-Score of Large Conventional and Large Islamic Bank

\begin{tabular}{ccccccc}
\hline Large Bank & $\mathbf{2 0 1 6}$ & $\mathbf{2 0 1 5}$ & $\mathbf{2 0 1 4}$ & $\mathbf{2 0 1 3}$ & $\mathbf{2 0 1 2}$ & Average Z Score \\
Meezan Bank & 78 & 55 & 79 & 60 & 25 & 59 \\
Habib Bank & 48 & 356 & 41 & 50 & 29 & 105 \\
\hline
\end{tabular}

Source: Annual Report, Pakistani Banks

However, on an individual basis from 2016 to 2012, Bank Al Baraka has minimum z-score is 7 in the year of 2012 while maximum Z-score of the same time frame of Bank Al Baraka is 101 in the year of 2015 for Islamic banking. On the other hand, HBL has maximum Z-score 886 in the year of 2016 while Askari Bank Ltd has minimum z-sore is 3 in the year of 2013 in the conventional banking sector. In the continuation, it has been also identified and determined during computation and analysis of $z$-score of both industry Islamic as well as conventional bank that small Islamic bank that is Bank Albaraka less financially stable and stronger as compare with small conventional bank that is Faysal Bank on the basis of average $\mathrm{z}$-score because bank albaraka has less average $\mathrm{z}$-score is 38 as compare with faysal bank has average $\mathrm{z}$-score is 274 as per Table 3 and it has been noted that in 2011, Faysal Bank has high z-score due to posit variation in return on asset, equity to asset and less volatility in returns.

Table 3. Average Z-Score of Small Conventional and Small Islamic Bank

\begin{tabular}{ccccccc}
\hline Small Bank & $\mathbf{2 0 1 6}$ & $\mathbf{2 0 1 5}$ & $\mathbf{2 0 1 4}$ & $\mathbf{2 0 1 3}$ & $\mathbf{2 0 1 2}$ & Average Z Score \\
Bank Albaraka & 30 & 101 & 43 & 11 & 7 & 38 \\
Faysal Bank & 259 & 31 & 93 & 113 & 876 & 274 \\
\hline
\end{tabular}

Source: Annual Report, Pakistani Banks

It is also proved and determined that during analysis of z-score that large Islamic Bank that is Meezan Bank Ltd less financially stable as compared with large conventional Bank that is Habib Bank Ltd on the basis of average z-score because Meezan Bank has less average z-score is 59 as compare with Habib Bank limited 
average $\mathrm{z}$-score is 105 as per Table 2. My $1^{\text {st }}$ finding that overall conventional banks are more financially stable and stronger than Islamic Banks in Pakistan on the basis of average Z-Score from 2012 to 2016 and these findings completely coincide with the finding of Youssef (2017), Wahid and Dar (2016) financial stability in Malaysian context, Shahid and Abbas (2012) in Pakistan context. Rokhim and Gamaginta (2009) do the research about financial stability in of Indonesia context and my $2^{\text {nd }}$ finding that large conventional bank has higher degree of financial stability than large Islamic bank match with the finding of Shahid and Abbas (2012) \& Wahid and Dar (2016) and my $3^{\text {rd }}$ finding that small conventional bank has higher degree of financial than small Islamic bank doesn't match with the finding of Cihak and Hesse (2010) and it may be possible due to extra ordinary performance of small Islamic bank, large sample frame used by researcher and combination of different Islamic bank which is running in different countries and these may be possible reason.

Figure 1 is quick comparison and review of average Z-Score for Conventional and Islamic banks from 2012 until 2016. Conventional banks are more financially stable and stronger than Islamic banks.

Figure 1: Average Z-Score Analysis for Conventional and Islamic Banking

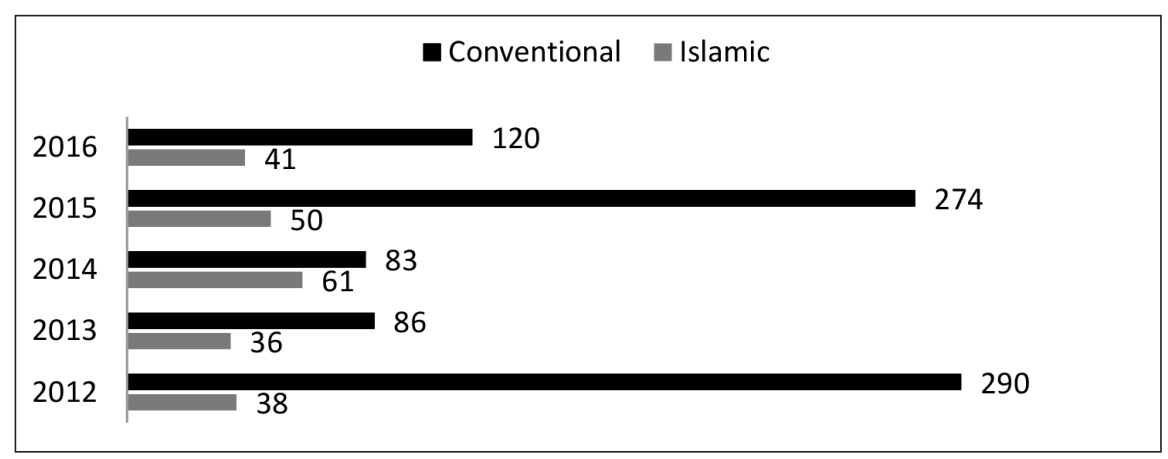

Source: Annual Report, Pakistani Banks

\section{Average Z-Score Analysis Islamic Bank Wise: Measuring Stability}

Average Z-score analysis (2012-2016) Islamic bank wise in Table 4 below indicate that Meezan Bank Ltd (MBL) is financially stronger, healthy and stable as a whole in all Islamic banks because MBL has highest z-score is 59 in all Islamic banks. Higher z-score may be caused by the higher return of asset its means management are efficient and they able to use bank asset in an efficient and effective manner for generation of earning and maximization of profit. The second reason for higher z-score may be caused by higher equity to asset it indicates that bank has high liquidity and 
banks are using own money for its operation. It assistances a bank to elude suffering financial uncertainty and distress during economic recessionary curses and third reason for higher z-score may be caused by lower standard deviation of return of asset its indicate that stability in return volatility and management are efficient to cope the situation of risk. The Average Z-score of Bank Islami is 44 that are higher than Dubai Islamic Bank and Al Baraka Bank. Its indicate that Bank Islami financially stronger, healthy and stable than Dubai Islamic and Al Baraka Bank. The Average Z-score of Dubai Islamic is 39 that are greater than Al Baraka Bank. It indicates that Dubai Islamic Bank in Pakistan is financially stable and stronger than Al Baraka Bank. Al Baraka Bank has lowest $\mathrm{z}$ score is 38 in all 4 Islamic Bank that is operating full-fledged in Pakistan. It means that on the basis of average $\mathrm{z}$ score analysis Bank Al Baraka is less stable and not financially stronger in all 4 Islamic.

Table 4: Average Z-Score Islamic Bank Wise Analysis

\begin{tabular}{ccccccc}
\hline Islamic & $\mathbf{2 0 1 6}$ & $\mathbf{2 0 1 5}$ & $\mathbf{2 0 1 4}$ & $\mathbf{2 0 1 3}$ & $\mathbf{2 0 1 2}$ & Average (2012-2016) \\
Meezan Bank & 78 & 55 & 79 & 60 & 25 & 59 \\
BankIslami & 25 & 19 & 97 & 45 & 34 & 44 \\
Dubai Islamic Bank & 30 & 23 & 24 & 29 & 87 & 39 \\
Al Baraka Bank & 30 & 101 & 43 & 11 & 7 & 38 \\
\hline
\end{tabular}

Source: Annual Report, Pakistani Banks

Figure 2 gives a quick review of average z-score of Islamic Banks from 2012 to 2016. Meezan Bank Ltd is financially stable in overall 4 Islamic banks. It is because $\mathrm{z}$-score of Meezan Bank is high that is mentioned in the Figure 2.

Figure 2: Islamic Bank Wise Average Z-Score (2012-2016)

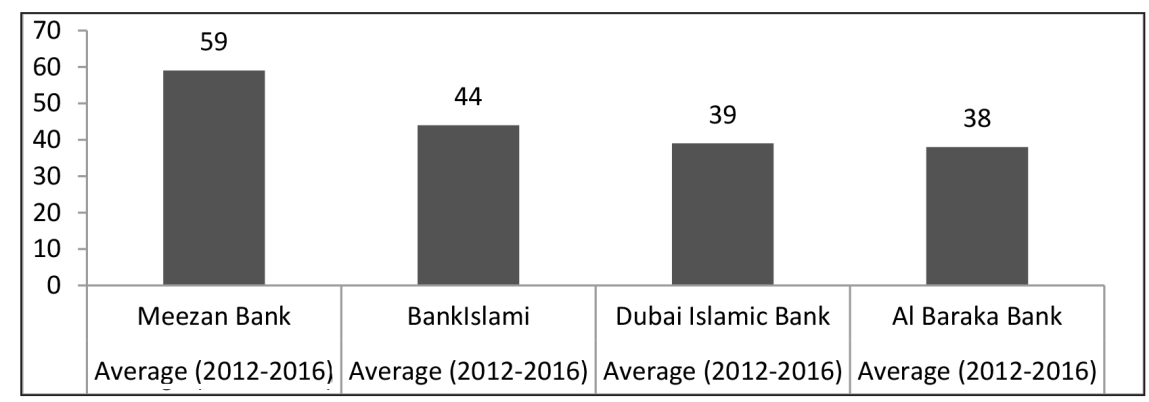

Source: Annual Report, Pakistani Banks 


\section{Average Z-Score Analysis Conventional Bank Wise: Measuring Stability}

Average Z-score analysis (2012-2016) Conventional Bank wise in Table 5 below indicate that Faysal Bank is financially stronger, healthy and stable as a whole in all conventional bank because Faysal Bank has highest z-score is 274 in all conventional banks. Higher z-score may be caused by the higher return of asset its means management are efficient and they able to use bank asset in an efficient and effective manner for generation of earning and maximization of profit. The second reason for higher z-score may be caused by higher equity to asset it indicates that bank has high liquidity and banks are using own money for its operation. It assistances a bank to elude suffering financial uncertainty and distress during economic recessionary curses and third reason for higher z-score may be caused by lower standard deviation of return of asset its indicate that stability in return volatility and management are efficient to cope the situation of risk. The Average Z-score of Habib Bank is 254 that are higher than Allied Bank and Askari Bank. Its indicate that Habib Bank financially stronger, healthy and stable than Allied Bank and Askari Bank and HBL is $2^{\text {nd }}$ highest in average financial stability from 2012 to 2016. The Average Z-score of Allied Bank is 104, which are greater than Askari Bank. It indicates that Allied Bank in Pakistan is financially stable and stronger than Askari Bank and Askari Bank is $3^{\text {rd }}$ highest in the category of average financial stability of the conventional bank. Askari Bank has lowest z score is 50 in all 4 conventional Bank that is operating as a commercial bank in Pakistan. It means that on the basis of average $\mathrm{z}$ score analysis Askari bank is less stable and not financially stronger in all 4 commercial bank in Pakistan.

Table 5. Z-Score Conventional Bank Wise Analysis

\begin{tabular}{ccccccc}
\hline Conventional & $\mathbf{2 0 1 6}$ & $\mathbf{2 0 1 5}$ & $\mathbf{2 0 1 4}$ & $\mathbf{2 0 1 3}$ & $\mathbf{2 0 1 2}$ & AverAverage (2012-2016 \\
Faysal Bank & 259 & 31 & 93 & 113 & 876 & 274 \\
HBL Bank & 87 & 886 & 165 & 93 & 38 & 254 \\
Allied Bank & 61 & 59 & 69 & 136 & 194 & 104 \\
Askari Bank & 71 & 118 & 4 & 3 & 53 & 50 \\
\hline
\end{tabular}

Source: Annual Report, Pakistani Banks

Figure 3, It is clearly mentioned that Faysal Bank is financially stable in overall 4 conventional Bank that is operating as a commercial bank in Pakistan because average z-score of Faysal Bank from 2012 to 2016 is high that is declared in the Figure 3. 
Figure 3: Conventional Bank Wise Average Z-Score (2012-2016)

$\left.\begin{array}{|r|c|c|c|c|}\hline 300 \\ 250 \\ 200 \\ 150 \\ 100\end{array}\right]$

Source: Annual Report, Pakistani Banks

\section{Equity to Total Asset: Measuring Liquidity}

As per Table 6, it is clearly identified that on overall average basis equity to total asset ratio of conventional banks is higher during sample frame from 2012 to 2016 and on the basis of this indicator conventional banks in Pakistan are stable as compare with Islamic banks. Throughout each year conventional banks have higher equity to asset ratio than Islamic banks except the 2012-year. High borrowing and loan taken by banks for running of operation and project may cause it. It reveals that conventional bank using own money for its operation and their liquidity is high as compared with Islamic bank on an average basis. Islamic banking liquidity, nevertheless, cannot be repudiated because the ratios of Islamic banks are also high on an average basis but as a whole comparison on average basis conventional banks are more stable and have higher liquidity and 6.09\% higher equity ratio of conventional banks on an average basis as compared with Islamic banks on an average basis. It means that it will be assistances conventional banks to elude suffering financial uncertainty and distress during economic recessionary curses because of higher liquidity and they are able to cope the worst situation and distress during uncertainty in financial position. These findings completely coincide with Ibrahim (2015) research finding.

We can see the quick comparison in Figure 4, it self-explanatory and clearly indicate that conventional banks on average basis have more liquidity on an average basis and they are more able to cope the uncertain situation (if occurred) during the future financial year due to macro and micro variable uncertainty. In only 2012 conventional banks on average basis have less equity ratio as compare with Islamic Banks. High borrowing and loan taken by conventional banks for running of operation and project may cause it. Thus, the conventional bank is enjoying a greater liquidity level than its opposing bank based on average equity to the asset. 
Table 6: Equity to Total Asset Analysis-Measuring Liquidity

\begin{tabular}{cccccc}
\hline Islamic & $\mathbf{2 0 1 6}$ & $\mathbf{2 0 1 5}$ & $\mathbf{2 0 1 4}$ & $\mathbf{2 0 1 3}$ & $\mathbf{2 0 1 2}$ \\
Meezan Bank & 4.633 & 4.95 & 5.46 & 5.74 & 6.04 \\
BankIslami & 6.88 & 6.42 & 6.73 & 7.19 & 7.53 \\
Dubai Islamic Bank & 7.96 & 5.08 & 7.33 & 8.68 & 10.81 \\
Al Baraka Bank & 8.98 & 7.22 & 6.25 & 6.66 & 8.15 \\
Average & $\mathbf{7 . 1 1}$ & $\mathbf{5 . 9 2}$ & $\mathbf{6 . 4 4}$ & $\mathbf{7 . 0 7}$ & $\mathbf{8 . 1 3}$ \\
Average (2012-2016) & $\mathbf{6 . 9 3}$ & & & & \\
\hline Conventional & $\mathbf{2 0 1 6}$ & $\mathbf{2 0 1 5}$ & $\mathbf{2 0 1 4}$ & $\mathbf{2 0 1 3}$ & $\mathbf{2 0 1 2}$ \\
HBL Bank & 7.83 & 8.23 & 9.1 & 8.29 & 8.24 \\
Allied Bank & 9.4 & 9 & 9.6 & 9.02 & 8.21 \\
Askari Bank & 5.26 & 5.01 & 5.3 & 4.74 & 5.58 \\
Faysal Bank & 7.88 & 7.06 & 6.78 & 6.27 & 6.72 \\
Average & 7.59 & 7.33 & 7.70 & 7.08 & 7.19 \\
Average (2012-2016) & 7.38 & & & & \\
\hline
\end{tabular}

Source: Annual Report, Pakistani Banks

Figure 4. Average Equity to Total Asset (2012-2016)

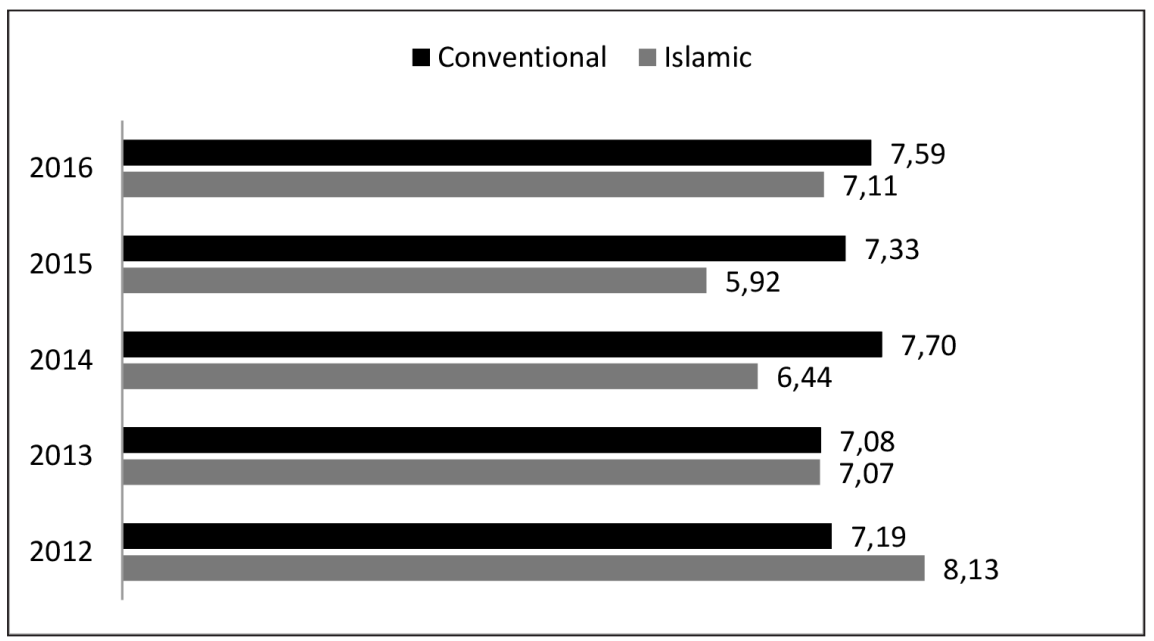

Source: Annual Report, Pakistani Banks 


\section{Capital Adequacy: Measuring Capital}

In Table 7, the average of Capital Adequacy Ratio (CAR) is 13.62 for Islamic banks and 14.92 for Conventional banks.. Again, conventional banks outperform than Islamic banks on the basis of this indicator. It is clearly identified that on overall average basis Capital Adequacy Ratio of conventional banks is higher during sample frame from 2012 to 2016. According to the regulatory requirement in Pakistan at the end of the year 2016, Banks are required to maintain 10.65 capital adequacy ratios. We can see that in table 6 both Islamic and conventional banks on average capital adequacy ratio basis are stable. At the end of the year 2016, we can see in Table 6 both Conventional and Islamic has more than 10.65 capital adequacy ratios. It shows that all Conventional, as well as Islamic banks, are ensuring compliance with regularity requirement to maintaining minimum 10.65 Capital Adequacy except Bank Albaraka Bank. The adequacy ratio of Bank Albaraka is 10.26 at the end of the year 2016 .

Table 7. Capital Adequacy Analysis

\begin{tabular}{cccccc}
\hline Islamic & $\mathbf{2 0 1 6}$ & $\mathbf{2 0 1 5}$ & $\mathbf{2 0 1 4}$ & $\mathbf{2 0 1 3}$ & $\mathbf{2 0 1 2}$ \\
Meezan Bank & 12.91 & 10.98 & 11.80 & 14.48 & 14.08 \\
BankIslami & 13.43 & 12.34 & 16.70 & 15.37 & 15.13 \\
Dubai Islamic Bank & 11.22 & 11.13 & 17.08 & 14.59 & 19.06 \\
Al Baraka Bank & 10.26 & 14.54 & 14.24 & 11.97 & 11.18 \\
Average & $\mathbf{1 1 . 9 6}$ & $\mathbf{1 2 . 2 5}$ & $\mathbf{1 4 . 9 6}$ & $\mathbf{1 4 . 1 0}$ & $\mathbf{1 4 . 8 6}$ \\
Average (2012-2016) & $\mathbf{1 3 . 6 2}$ & & & & \\
Conventional & $\mathbf{2 0 1 6}$ & $\mathbf{2 0 1 5}$ & $\mathbf{2 0 1 4}$ & $\mathbf{2 0 1 3}$ & $\mathbf{2 0 1 2}$ \\
HBL Bank & 15.50 & 17.00 & 16.20 & 15.40 & 15.30 \\
Allied Bank & 20.84 & 20.85 & 19.75 & 17.85 & 16.17 \\
Askari Bank & 12.50 & 12.51 & 13.03 & 10.39 & 11.81 \\
Faysal Bank & 14.62 & 14.41 & 12.22 & 11.29 & 10.69 \\
Average & $\mathbf{1 5 . 8 7}$ & $\mathbf{1 6 . 1 9}$ & $\mathbf{1 5 . 3 0}$ & $\mathbf{1 3 . 7 3}$ & $\mathbf{1 3 . 4 9}$ \\
Average (2012-2016) & $\mathbf{1 4 . 9 2}$ & & & & \\
\hline
\end{tabular}

Source: Annual Report, Pakistani Banks

It may be caused by credit, operational risk, and market risk. In order to the maintained minimum requirement of CAR, Bank Albaraka required to minimized operational, market and credit risk and to make enhance due diligence at the time 
of credit and financing approved to the customer and to minimize the risk level in the different portfolio and to make sure all policy and procedure are implemented with absolute compliance. According to State Bank of Pakistan, the minimum capital requirement of banks in Pakistan is 10 Billion. If banks are not meeting this requirement than banks are going for closer to business and merger and acquisition. The current example of the closure of Pakistan operation is HSBC bank. HSBC Pakistan operation takes over from Meezan Bank Limited and simultaneously another example of Burj Bank take over by Bank Albaraka. NIB bank in Pakistan merged with MCB bank. There are also several other reasons for merger and acquisition but the main important factor is a capital requirement. These findings completely coincide with the finding of Verbeet (2014).

Looking at Figure 5, it is self-explanatory and clearly indicate that conventional banks on an average basis from 2012 to 2016 are more stable as an indicator of capital adequacy as compare with Islamic banks.

Figure 5: Average Capital Adequacy Ratio (2012-2016)

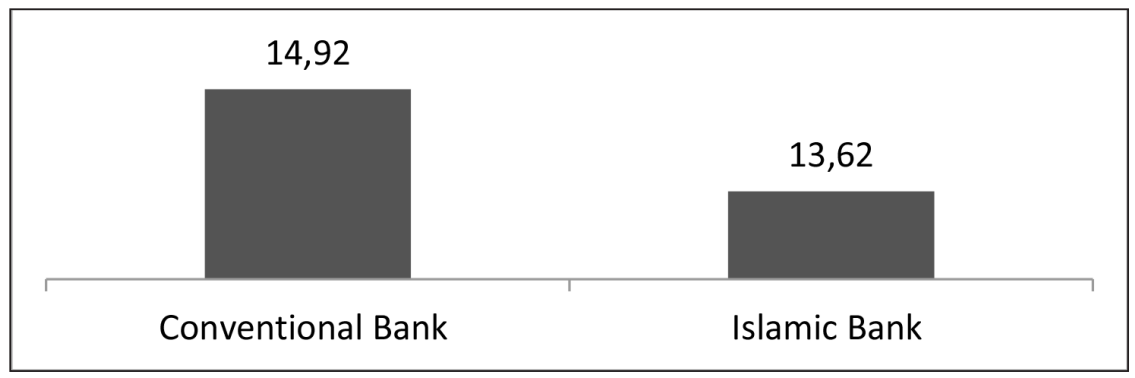

Source: Annual Report, Pakistani Banks

According to Z-Score analysis and finding, it has been determined that overall conventional banks are more financially stable and stronger than Islamic Banks in Pakistan on the basis of average Z- Score and these findings completely coincide with the finding of Mustafa Haj Youssef (2017) Gulf region, (Wahid and Dar 2016) financial stability in Malaysian context, Shahid and Abbas (2012) in Pakistan context and Rokhim and Gamaginta (2009) financial stability in of Indonesia context. Large conventional bank has higher degree of financial stability than large Islamic bank on the basis of average Z-Score and finding match with the finding of Shahid and Abbas (2012) \& Wahid and Dar (2016) and small conventional bank has higher degree of financial than small Islamic bank and our finding doesn't match with the finding of Cihak and Hesse (2010) and it may be possible due to extra 
ordinary performance of small Islamic bank, large sample frame used by researcher and combination of different Islamic bank which is running in different countries and these may be possible reason. It has been determined and identified that on the basis of average Z-score, Meezan Bank Ltd (MBL) is financially stronger, healthy and stable as a whole in all Islamic banks because MBL has highest z-score in all Islamic banks. Higher z score may be caused by the higher return of the asset.

The second reason for higher z-score may be caused by higher equity to asset and third reason for higher z-score may be caused by lower standard deviation of return of the asset. Faysal Bank is financially stronger, healthy and stable as a whole in all conventional banks on the basis of average Z-Score and it may be caused due to posit variation in equity to return, return of asset and less volatility in return. Equity to total asset ratio of conventional banks is higher and on the basis of this indicator conventional banks in Pakistan are stable as compare with Islamic banks. These findings are in line with the findings of Ibrahim (2015). According to Capital Adequacy ratio as financial soundness indicator, it has been determined that conventional banks outperform than Islamic banks. The adequacy ratio of Bank Albaraka is 10.26 at the end of the year 2016 which is less than the minimum requirement of regularity Authority State Bank of Pakistan. Only $3.7 \%$ capital adequacy ratio of Bank AL Baraka deviates from the minimum requirement that is 10.65. There is some limitation for invest and financing activities in the different project due to Shariah compliance for Islamic banks. In order to achieve a higher rate of return, it is suggested to invest in a diversified portfolio and avoid that investment that has a high-risk level. These findings completely coincide with the finding of Verbeet (2014).

\section{Conclusion}

It has been found that when capitalization of the bank's increases, the financial stability of banks also increases. When the return of asset of the bank's increases, the financial stability of banks also increase. When volatility of banks returns decrease, the financial stability of banks also increase. When capital adequacy ratio of banks decreases or less than minimum regularity requirement 10.65 as per SBP, the financial stability of banks will be decreased. When credit, operational and operational risk of banks increases, the degree of stability will be decreased.

Bank financial stability is playing a very important role in the development of the economy; therefore, we will suggest following suggestion that directly and indirectly impacts on bank financial stability and soundness. Banks Nonperforming loan (NPL) must be minimized and advance to deposit is in control in the banks and to increase branch network Pan Pakistan or Globally, therefore, 
banks are able to receive more deposit from the customer and they can utilize in the different investment project in order to get maximize profit. Investment in a diversified portfolio is also required in order to reduce risk level, volatility in return and increase capitalization of the bank. The banks are also required to follow strict compliance policy in State Bank regulation and other country regulation like Foreign Account Tax Compliance Act (FATCA) because noncompliance of any regulation bank faces heavy penalty that impacts on bank financial stability and Enhanced Due Diligence and effective risk assessment in term of customer personal profile and business profile are required before financing approved for the customers. Non-compliance of due diligence that impacts on non-performing loan (NPL) and capital adequacy ratio. Information security is a big challenge nowadays for banking sector because technology has enhanced and almost customers are using online fund transfer and cash withdrawal instead of manually transfer and withdrawal. Electronic cards are using online purchasing and internationally. In most cases, it has been noted that PIN code of customer VISA card is misused in fraudulent activity that impacts on customer retention, deposit, and goodwill of banks. In order to mitigate electronic fraud, banks are required to developed and strong information security department.

There is still extensive scope for further enlargement, improvement, and research. Sample size and time frame can be extended for analysis and measure of financial stability and different countries of Islamic Banks and Conventional may be included in my sample size for measurement of the financial stability of joint country banks. More variable and financial soundness indicator may be added for measurement of financial stability. Further research may be extended why Islamic Banks are less financially stable as compare with conventional banks in Pakistan and impact of financial instability of banks on Pakistan economy.

\section{References}

Akhtar, M. F., Ali, K., \& Sadaqat, S. (2011). Liquidity Risk Management: a Comparative Study Between conventional and Islamic banks of Pakistan. Interdisciplinary Journal of Research in Business. Vol. 1(1): 35-44.

Altaee, H. H. A., Talo, I. M. A., \& Adam, M. H. M. (2013) Testing the Financial Stability of Banks in GCC Countries: Pre and Post Financial Crisis. International Journal of Business and Social Research (IJBSR). Vol. 3(4): 93-105.

Beck, T., Demirguç-Kunt, A., \& Merrouche, O. (2013). Islamic vs. Conventional Banking: Business Model, Efficiency, and Stability. Journal of Banking \& Finance. Vol. 37(2): 433-447. 
Bessis, J. (2010). Risk Management in Banking. West Sussex: John Wiley and Sons, Ltd.

Bitar, M., Madies, P., \& Taramasco, O. (2015). Comparing Islamic and Conventional Banks' Financial Characteristics: A Multivariate Approach. Available at: http://dx.doi.org/10.2139/ssrn.2571631.

Bourkhis, K., \& Nabi, M. S. (2013). Islamic and Conventional Banks' Soundness During the 2007-2008 Financial Crisis. Review of Financial Economics. Vol. 22(2): 68-77.

Chakroun, M. A., \& Gallali, M. I. (2015). Islamic Banks and Financial Stability: An Empirical Analysis of the Gulf Countries. International Journal of Business and Commerce. Vol. 5(3): 64-87.

Chapra, M.U. (2011). The Global Financial Crisis: Some Suggestions for Reform of the Global Financial Architecture in the Light of Islamic Finance. Thunderbird International Business Review. Vol. 53 (5): 565-579. doi: https:// doi.org/10.1002/tie.20435.

Chong, B. S., \& Liu, M. H. (2009). Islamic Banking: Interest-Free or InterestBased. Pacific Basin Finance Journal. Vol. 17: 125-144. doi: https://doi. org/10.1016/j.pacfin.2007.12.003.

Cihak, M., \& Hesse, H. (2010). Islamic Banks and Financial Stability: An Empirical Analysis. Journal of Financial Services Research. Vol. 38(2-3): 95-113. doi: https://doi.org/10.1007/s10693-010-0089-0.

Demirguç-Kunt, A. \& Detragiache, E. (2009). Basel Core Principles and Bank Soundness. Policy Research Working Paper No. 5129. Washington D.C: World Bank.

Farook, S., \& Hassan., M. K. (2015). Islamic Banks and Financial Stability: Further Evidence. In Asutay, M., \& Turkistani, A. Q. (ed). Islamic Finance: Risk, Stability and Growth (Vol 2), 13-54. Berlin: Gerlach Press.

Hasan, M., \& Dridi, J. (2010) The Effects of the Global Crisis on Islamic and Conventional Banks. IMF Working Paper No.10/201. Washington: International Monetary Fund

Ibrahim, M. (2015). A Comparative Study of Financial Performance Between Conventional and Islamic Banking in The United Arab Emirates. International Journal of Economics and Financial Issues. Vol. 5(4): 868-874.

Islam, M. U., \& Kozokov, S. (2009). Stability of Islamic and Conventional Banks, an Empirical Comparative Analysis. (Unpublished Master Thesis). Sweden: Lund University. 
Iqbal, Z., Askari, H. \& Krichenne, N. (2011). The Inherent Stability of Islamic Finance. In The Stability of Islamic Finance: Creating a Resilient Financial Environment for a Secure Future. New Jersey: John Wiley.

Iqbal, Z. \& Mirakhor, A. (2011). TheSstability of The Islamic Financial System. An Introduction to Islamic Finance: Theory and Practice. New Jersey: John Wiley.

Johnes, J., Izzeldin, M., \& Pappas, V. (2009). Efficiency in Islamic and Conventional Banks: A Comparison Based on Financial Ratios and Data Envelopment Analysis. Economics Working Paper Series. The Economics Department, Lancaster University.

Kassim, S. H. \& Majid, M. S. A. (2010). Impact of Financial Shocks on Islamic Banks Malaysian Evidence During 1997 and 2007 Financial Crises. International Journal of Islamic and Middle Eastern Finance and Management. Vol. 3(4): 291-305. doi: https://doi.org/10.1108/17538391011093243.

Nafla, A., \& Hammas, A. (2016). Islamic Banks, Conventional banks, and Subprime Crisis: Empirical Evidence by Using DEA Approach. Journal of Islamic Banking and Finance. Vol. 4(1): 10-21.

Odeduntan, A. K., Adewale, A. A., \& Hamisu, S. (2016). Financial Stability of Islamic Banks: Empirical Evidence. Journal of Islamic Banking and Finance. Vol. 4(1): 39-46.

Rahim, S. R. M., \& Zakaria, R. H. (2013). Comparison of stability between Islamic and conventional banks in Malaysia. Journal of Islamic Economics, Banking and Finance. Vol. 9(3): 131-149

Rajhi, W., \& Hassairi, S. A. (2013). Islamic Banks and Financial Stability: a Comparative Empirical Analysis Between MENA and Southeast Asian Countries. Région et Développement. Vol. 37: 149-177.

Rokhim, R. \& Gamaginta. (2009). The Stability Comparison Between Islamic Banks and Conventional Banks: Evidence in Indonesia. Proceeding Paper at 8th International Conference on Islamic Economics and Finance, 1-29. Qatar: Center for Islamic Economics and Finance, Qatar Faculty of Islamic Studies, Qatar Foundation.

Santoso, T., Rum, I. A., \& Patria, K. Z. (2016). Islamic and Conventional Banks Stability: A Comparative Analysis. Proceeding Paper at International Conference of Integrated Microfinance Management. Atlantis Press. Retrieved from: download.atlantis-press.com/php/download_paper.php?id=25864940

Shahid, M. A., \& Abbas, Z. (2012). Financial stability of Islamic banking in Pakistan: An empirical study. African Journal of Business Management. Vol. 6(10): 3706-3720. 
Siraj, K. K., \& Pillai, P. S. (2012). Comparative Study on The Performance of Islamic Banks and Conventional Banks in GCC region. Journal of Applied Finance and Banking. Vol. 2(3): 123-134.

Uhde, A., \& Heimeshoff, U. (2009) Consolidation in Banking and Financial Stability in Europe: Empirical Evidence. Journal of Banking and Finance. Vol. 33:1299-1311. doi: https://doi.org/10.1016/j.bankfin.2009.01.006.

Verbeet, M. (2014. Stability of Islamic Banks: A Comparison of Conventional and Islamic Banks. In Ahmed, H., Asutay, M., \& Wilson, R. (ed). Islamic Banking and Financial Crisis. 58-86. Edinburgh: Edinburgh University Press Ltd.

Wahid, M. A., \& Dar, H. (2016). Stability of Islamic versus Conventional Banks: A Malaysian Case. Jurnal Ekonomi Malaysia. Vol. 50(1): 111-132.

Youssef, M. H. (2017). Financial Stability of Islamic and Conventional Banks. (Unpublished Thesis). Sweden: Lund University. 